\title{
Importance of Duration,
} Duty-Cycling and Thresholds for the Implementation of Ultraviolet $\mathbf{C}$ in Marine Biofouling Control

\author{
Paul Whitworth ${ }^{1 *}$, Nick Aldred ${ }^{1,2}$, Kevin J. Reynolds ${ }^{3}$, Joseph Plummer ${ }^{4}$, Phillip W. Duke ${ }^{4}$ \\ and Anthony S. Clare ${ }^{1}$
}

${ }^{1}$ School of Natural and Environmental Sciences, Newcastle University, Newcastle upon Tyne, United Kingdom, ${ }^{2}$ School of Life Sciences, University of Essex, Colchester, United Kingdom, ${ }^{3}$ AkzoNobel, Gateshead, United Kingdom, ${ }^{4}$ Platform Systems Division, Defence Science and Technology Laboratory (DSTL), Ministry of Defence, Porton Down, Salisbury, United Kingdom

OPEN ACCESS

Edited by:

Eugene Georgiades, Ministry for Primary Industries,

New Zealand

Reviewed by:

Sriyutha Murthy,

Bhabha Atomic Research Centre,

India

Maria Salta

University of Portsmouth

United Kingdom

${ }^{*}$ Correspondence: Paul Whitworth

P.whitworth@newcastle.ac.uk

Specialty section:

This article was submitted to

Marine Biology,

a section of the journal

Frontiers in Marine Science

Received: 04 November 2021 Accepted: 30 December 2021 Published: 10 February 2022

Citation:

Whitworth P, Aldred N,

Reynolds KJ, Plummer J, Duke PW and Clare AS (2022) Importance of Duration, Duty-Cycling and Thresholds

for the Implementation of Ultraviolet $C$

in Marine Biofouling Control.

Front. Mar. Sci. 8:809011. doi: 10.3389/fmars.2021.809011
The introduction of a surface into the marine environment begins a process known as biofouling, which increases the weight and hydrodynamic drag of the fouled structure. This process is detrimental to maritime vessels and costs the industry $\sim \$ 150 \mathrm{~B}$ in fuel and maintenance spending annually. Preventing the settlement of fouling organisms mitigates these issues and limits the spread of non-indigenous species (NIS). This is primarily achieved via antifouling paints. Ultraviolet light is a sterilization method used in water purification, food storage packaging, and within medical fields. Ultraviolet $C$ (UV-C) radiation interacts with DNA to prevent growth, proliferation, and survival of bacteria, and biofilm formation. Recent progress in microelectronics technology has advanced the range of commercially available light-emitting diodes (LEDs) to include the UV wavelengths, and the reduced size and cost has allowed their integration into previously inaccessible locales. This study builds on recent progress in integrating UVC LEDs into UV-lucent silicone tiles for fouling control. The operational cycle needed to prevent growth of Navicula incerta cells was determined. Constant irradiance at a peak of $5.77 \mu \mathrm{W} / \mathrm{cm}^{2}$ resulted in a significant reduction in diatoms within $2 \mathrm{~h}$, and a 2 log and 3 log reduction after $48 \mathrm{~h}$ and 5 days, respectively. Duty cycling (pulsing) in all variations from 50 to $2.5 \%$, indicated significant reductions in cell densities, and the lowest cycle could effectively reduce biofouling growth and increase the longevity of the LEDs for up to 45.6 years. Irradiance and exposure were altered over a set duration and indicated a restriction in growth between $0.01-0.82 \mathrm{~J} / \mathrm{cm}^{2}$ and an increased mortality at irradiances $>2.65 \mathrm{~J} / \mathrm{cm}^{2}$, suggesting an effective antifouling threshold between these dosages. The effective dosage for 1 log reduction in fouling was estimated to be $25 \mathrm{~J} / \mathrm{cm}^{2}$ but varied according to irradiance delivery method. Effective dosage for a $1 \mathrm{log}$ reduction between experimental methods was variable indicating that UV treatment of $N$. incerta departed from the Bunsen-Roscoe reciprocity law expectancy. The variation in densities at similar dosages could be explained with further investigation of DNA repair mechanisms. In conclusion, UV-B/C use was effective at all irradiances, including as low as $0.01 \mathrm{~J} / \mathrm{cm}^{2}$, and holds considerable promise for marine biofouling control. 


\section{INTRODUCTION}

The accumulation of marine organisms on submerged surfaces, known as biofouling, is an ongoing challenge for the maritime industry. In aquaculture, biofouling increases the degradation of cages, can inhibit water exchange, and increases the potential of disease (Bannister et al., 2019). Powerplant cooling pipes that receive and deposit into the ocean can become clogged, reducing flow, and impacting internal temperature control (Flemming et al., 2009). Biofouling can occur on filtration membranes that are used for desalination of saltwater and reclamation of wastewater (Matin et al., 2021). The fouling of ships' hulls increases hydrodynamic drag, increasing fuel consumption and pollutant emissions (Munk et al., 2009). Fouling of hulls and internal ballast tanks also transports non-indigenous species (NIS), which can be ecologically detrimental to native species, as well as impacting upon farmed aquaculture species, submerged static artificial structures, and presenting risks to marine values (Sylvester et al., 2011; Piola and Hopkins, 2012; Georgiades et al., 2020, 2021; Hopkins et al., 2021).

Marine biofouling was estimated to cost the US Navy \$56 million p.a. for the DDG-51 class alone, with estimates as high as $\sim \$ 150$ billion for annual fuel cost savings to the global shipping fleet derived from effective antifouling coatings (Pritchard, 1988; Maréchal and Hellio, 2009; Schultz et al., 2011; Selim et al., 2017). Estimates can vary markedly based on the prevailing oil price. Since 2017 prices have ranged from $\$ 11.26$ to $\$ 75.23$ per barrel (WTI crude oil) and are currently $\sim \$ 25$ (60\%) per barrel more than when estimates were last calculated (Selim et al., 2017; MacroTrends, 2021), which could adjust current estimates to as high as $\sim \$ 240$ billion.

Marine biofouling is an expansive industrial problem that is well-studied, with multiple reviews focusing on or around specific niches (Pritchard, 1988; Dobretsov et al., 2013). Methods to limit fouling on ships include biocidal treatment, interference with adhesion, settlement deterrence, and physical removal of foulers (Han et al., 2021; Liu et al., 2021; Pistone et al., 2021). Between these groups many strategies have been developed, ranging from electrochlorination to biocidal products (Growcott et al., 2017), self-polishing and controlled depletion paints (Almeida et al., 2007), fouling-release coatings (Lejars et al., 2012), and the development of new experimental approaches (Li et al., 2020). Currently, the most prevalent method for ships is the use of biocidal paints, which can be used on the hull and in niche areas, such as sea chests (Kiil et al., 2002). These paints are optimal for the hull but are often applied to sea chests, even though they are not designed for these areas, and perform poorly due to the different flow regimes (Coutts et al., 2003; De Castro et al., 2018). The hull experiences smooth flow whilst in motion, but niche areas (propellers, sea-chests, bilge intakes, etc.) are subjected to regimes that can remove or rapidly deplete paints, or restrict paint leaching (Coutts and Taylor, 2004; Coutts and Dodgshun, 2007; Sylvester and MacIsaac, 2010). The inhibition of early forming biofilms has been proposed as a means to counteract macrofouling, by interfering with the proposed successional development of a fouling community (Hadfield and Paul, 2001; Hadfield, 2011; Salta et al., 2013). Under this scenario, the biofouling process begins with the formation of a conditioning layer providing nutrients for subsequent adhering organisms (Wahl and Lafargue, 1990; Railkin, 2003; Grzegorczyk et al., 2018). Next, bacteria and diatoms use the nutrient-rich conditioning layer to produce an exopolymeric material resulting in a biofilm (Dang and Lovell, 2016). Diatoms are associated with early colonization of surfaces and are ubiquitous in their distribution (Hunsucker et al., 2014; Gómez-Ramírez et al., 2019). Diatomaceous biofilms can increase vessel hull friction by up to $70 \%$ based on the biofilm's thickness and percentage coverage; this can require increases in vessel power between 1.5 and $10.1 \%$ (Schultz et al., 2015). Biofilm formation is dependent on the physical and chemical conditions of the water, such as temperature and chemical input, and is vulnerable to unfavorable conditions (Cacabelos et al., 2020). Biofilms may then induce larval settlement and allow the formation of a macrofouling layer of juvenile barnacles, mussels, ascidians, polychaetes, and algal spores. While this process is generally considered to be successional (Scheer, 1945; Wahl, 1989; Bloecher et al., 2013; Chen et al., 2013), this is not always the case and many fouling organisms, which are opportunistic by nature, exhibit settlement inhibition or ambivalence in the presence of a biofilm (Roberts et al., 1991; Clare et al., 1992; Hadfield and Paul, 2001; Callow and Callow, 2011; Salta et al., 2013; Piola et al., 2016). As bacteria and single-celled organisms, such as diatoms, are particularly susceptible to ultraviolet (UV) light, its use as an antifouling strategy has generated interest both for the prevention of biofilm formation and possible knock-on effects to macroscopic biofouling prevention.

UV irradiation is used for sterilization in many industries including water purification, sewage treatment, medical surface cleansing, food preservation, and in scientific laboratories for routine sterilization of equipment. The UV spectrum is divided into ranges of wavelengths; 340-400 nm (UV-A), 280-340 nm (UV-B), and 100-280 $\mathrm{nm}$ (UV-C), and inactivates organisms most effectively at $254 \mathrm{~nm}$ (UV-C; Zelle, 1960). By isomerizing hydrogen bonds between purine and pyrimidine base pairs, when there are two of the same adjacent pyrimidines, the neighboring base pairs bond together producing a photolesion in the form of a cyclobutane pyrimidine dimer (CPD) or 6-4 photoproduct (6-4 PP; Schreier et al., 2009). In algae, these lesions cause a distortion in the structure of DNA, which fail a DNA assessment during photosystem II. This can lead to a failure in cell division and reproduction, and can cause cell apoptosis (Szabó and Ohshima, 1997). The impediment to proliferation has the potential to halt biofilm formation and inhibit fouling by organisms that require a biofilm for settlement. Additionally, evidence suggests that macrofouling larvae are more susceptible to UV light than adult phases, indicating that settlement could be prevented and macrofouling inhibited with continuous exposure (Kuffner, 2001; Hunsucker et al., 2019).

The use of UV sterilization has become more prevalent as technology has progressed and the costs and scale of the light sources have reduced. Mono- and polychromatic halogen lamps provide a high irradiance capacity but, due to their size, remain unfeasible for many applications. UV light-emitting diodes (LEDs) have improved since the early 2000s and are now 
commercially available at a reasonable scale and cost (Bugbee, 2017). This has allowed for technological integration where UV use was not previously considered.

The use of UV-C LEDs for biofouling control was investigated by Piola et al. (2016), using a tile design that incorporated UV-C LEDs in a UV transparent silicone, allowing continual surface irradiance, and investigating settlement diversity over time. Unfortunately, some LEDs failed during operation. The LEDs that remained operational over the duration of the project maintained a fouling free surface within a radius of the light source. An estimated threshold irradiance of $1 \mu \mathrm{W} / \mathrm{cm}^{2}$ was identified. The low power requirement and high efficacy of the UV sterilization technique confirmed the high potential of UV LEDs as a potential new avenue for the antifouling industry.

Using the initial findings of Piola et al. (2016), this study aimed to determine the efficacy of UV-B/C LED-embedded tiles in inhibiting biofouling over varying exposure durations, duty cycle periods, and fluence rates to establish a range of thresholds for these factors. For our experiments, we used a laboratory model biofilm-forming diatom, Navicula incerta. To determine thresholds, the minimum dosages required to attain a significant reduction in growth and removal followed by a $1 \mathrm{log}$ reduction in the density of exposed organisms was investigated. By comparing settlement and survival, a novel UV-C based antifouling approach that is effective may be achievable.

\section{MATERIALS AND METHODS}

\section{Units and Nomenclature}

Throughout this manuscript, irradiances (a radiant flux which a surface receives per unit area- $\mu \mathrm{W} / \mathrm{cm}^{2}$ ) were measured using an ILT 950 spectroradiometer by taking a reading at the experimental surface. These measures were treated as the surface irradiance, which gave individual $\mathrm{nm}$ irradiances and total UV$\mathrm{B} / \mathrm{C}$ spectral range irradiances. The term fluence (units $\mathrm{J} / \mathrm{cm}^{2}$ ) is used interchangeably with UV dose. Fluence/dose is the amount of irradiance the organisms were exposed to over a given time (in seconds). The quantum yield, and how much of the dose was absorbed by individual organisms, was not measured. The UV dose was determined by taking an irradiance reading at the experimental surface and multiplying it by the duration of exposure in seconds. All rates and dose measurements were compiled and are supplied in Supplementary Table 1.

\section{Methods and Materials}

A total of four tiles (two irradiated and two control) were produced with a $2 \times 2$ array of UV (265-300 nm) LEDs embedded $1 \mathrm{~cm}$ beneath the surface of a $70 \times 70 \times 25 \mathrm{~mm}$ Lumisil $^{\circledR} 400$ (Wacker) silicone polymer (Figure 1). To degas the Lumisil ${ }^{\circledR} 400$, it was cured at $-0.1 \mathrm{MPa}$ within a Medline Scientific $^{\mathrm{TM}}$ Jeio Tech $665 \mathrm{~L}$ vacuum oven (OV-12) over $48 \mathrm{~h}$ at $70^{\circ} \mathrm{C}$. This prevented bubble formation on the surface and allowed optimal internal cross-linking.

Supplier recommendations stipulated that LED power requirement was $24 \mathrm{~V}$ and 0.17 amps per LED to achieve an expected $10,000 \mathrm{~h}$ of dependable performance. This was used as

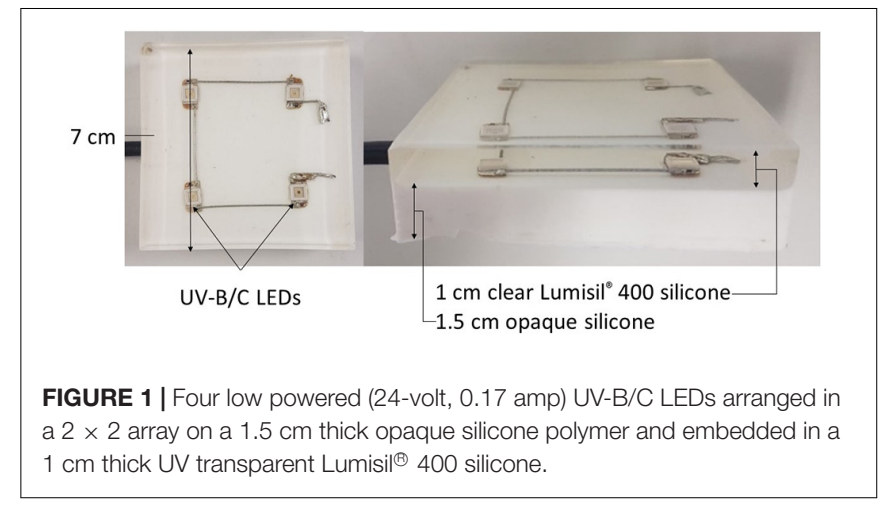

the standard operating power supply and only altered in specific experiments, as described below.

Diatoms, Navicula incerta were chosen as a representative slime-forming species; a major challenge for contemporary nonbiocidal fouling-release coatings (Schultz et al., 2015). N. incerta strain UTEX B 2046 from the culture collection at the University of Texas in Austin, United States was cultured following Kardela et al. (2019), and were used for experiments on day 5 of culture, at the peak of their exponential growth phase. Cells were agitated and suspended before experimentation, allowing the cell density to be calculated. The culture was then diluted with F/2 medium to give a 150,000 cells $/ \mathrm{mL}$ culture. To the surface of the tiles, $20 \mathrm{~mL}$ of the 150,000 cells/mL culture was added and allowed $2 \mathrm{~min}$ to acclimate before irradiance was initiated. Tiles were split into irradiated and control, and operated in replicates of five for durations of $2 \mathrm{~h}, 1,2,3,4$, and 5 days. After the allotted exposure duration, tiles were transferred to fresh artificial seawater (ASW) made to 33 ppt using Tropic Marin ${ }^{\circledR}$ salts and placed on an orbital shaker for $5 \mathrm{~min}$ as a wash step. The wash step allowed any deceased and non-adhered $N$. incerta to be removed from the surface so that differences between viable cell densities could be determined.

Cells remaining adhered were photographed using an epifluorescence microscope (Leica DMi8 with Texas Red filter set, 570-600 EX and 604-644 EM). To control for possible uneven coverage, 30 fields of view were taken at randomly chosen locations (Callow and Callow, 2002), three of which were counted manually for comparison to subsequent automated counts. These were made using Image J software by converting images to 16-bit format, altering the threshold to isolate cells from the surface, and counting with a minimum pixel count of 35 and curvature of 0.2 . All cell count survival and settlement data were then subjected to generalized linear modeling (GLM) and statistical analysis using R 4.0.0 (R Core Team, 2021).

The method described above was used for the pulsing study, which was conducted after the completion of the initial study but varied with irradiance supplied in periods of $20 \mathrm{~min}$ according to the following duty cycles: $10: 10,5: 15,2.50: 17.50,1: 19$, and 0.50:19.50 (irradiated: no irradiance). Experiments were run for 2 days, based on findings from the diatom settlement study.

To determine thresholds for survival of diatoms, the irradiance was altered by controlling the voltage to the tiles. 
Diatom cultures and methodology otherwise followed the same protocol as above. Irradiance was measured using an ILT 950 spectroradiometer (Supplementary Table 1). The irradiance of the LEDs at the tile surface was $108 \mu \mathrm{W} / \mathrm{cm}^{2}$ at full power over the UV-B/C range and peaked at $5.77 \mu \mathrm{W} / \mathrm{cm}^{2}$ (Figure 2). Based on these findings, voltage experiments were conducted with increments from 18 to $24 \mathrm{~V}$. Settlement and survival of $N$. incerta were measured and statistically compared for all voltage increments. Smooth line plots were generated using a t-based approximation, and GLM, where the normal confidence interval is constructed on the link scale and then backtransformed to the response scale within the ggplot2 package using the geom_smooth function (Wickham, 2016).

\section{RESULTS}

\section{Tile Specifications}

Tile irradiance was measured, using an ILT 950 spectroradiometer, at the water-tile interface directly over the LEDs and at the center of each tile. The mean irradiance from all tiles was $108.23 \mu \mathrm{W} / \mathrm{cm}^{2}$ with an average peak irradiance of $5.77 \mu \mathrm{W} / \mathrm{cm}^{2}$ at $281 \mathrm{~nm}$, which did not vary significantly between the LEDs $(P>0.05)$, and had a wavelength range from 265 to $300 \mathrm{~nm}$ (Figure 2). There was some substantial drop off in fluence based on the tile surface location (Figure 2). These variations were taken into consideration in the design of experiments.

The irradiances for LEDs used in this study were determined at $18 \mathrm{~V}\left(0.07 \mu \mathrm{W} / \mathrm{cm}^{2}\right), 19 \mathrm{~V}\left(0.88 \mu \mathrm{W} / \mathrm{cm}^{2}\right), 20 \mathrm{~V}\left(4.76 \mu \mathrm{W} / \mathrm{cm}^{2}\right)$, $21 \mathrm{~V}\left(15.32 \mu \mathrm{W} / \mathrm{cm}^{2}\right), 22 \mathrm{~V}\left(36.04 \mu \mathrm{W} / \mathrm{cm}^{2}\right), 23 \mathrm{~V}(64.34$ $\left.\mu \mathrm{W} / \mathrm{cm}^{2}\right)$, and $24 \mathrm{~V}\left(108.23 \mu \mathrm{W} / \mathrm{cm}^{2}\right)$. These gave fluence values over $48 \mathrm{~h}$ of $0.01,0.15,0.82,2.65,6.23,11.12$, and $18.70 \mathrm{~J} / \mathrm{cm}^{2}$, respectively (Figure 3 ).

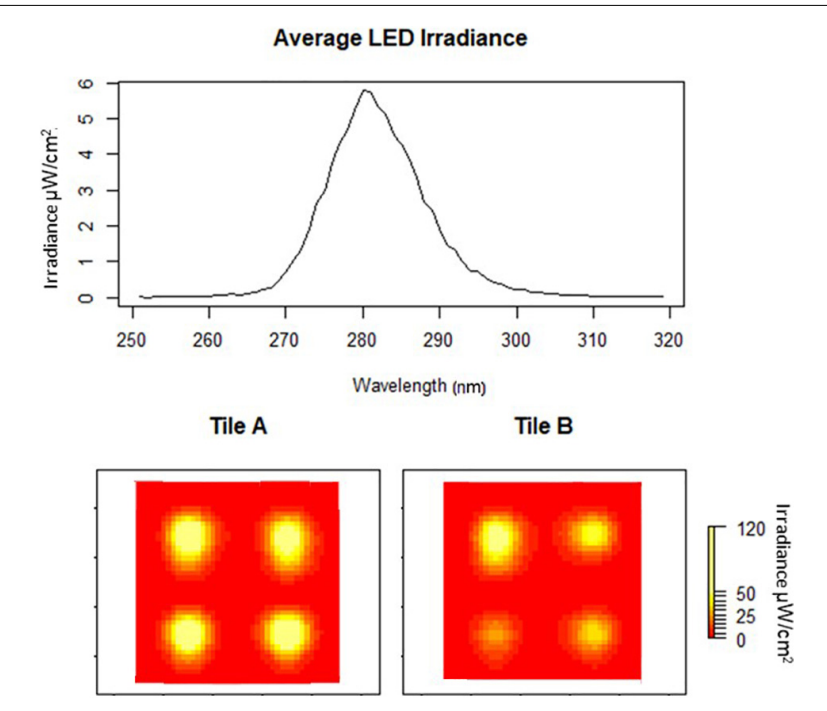

FIGURE 2 | Average peak wavelength of eight LEDs embedded in two tiles at 24 volts $(\mathbf{A}, \mathbf{B})$. Heat maps of individual tile irradiances (yellow high and red low).

\section{Duration of Exposure to Irradiance}

Exposure durations of $2 \mathrm{~h}, 1,2,3,4$, and 5 days produced fluences of $0.78,9.35,18.70,28.05,37.40$, and $46.75 \mathrm{~J} / \mathrm{cm}^{2}$, respectively (Supplementary Table 1). For the controls, of the total 150,000 cells $/ \mathrm{mL}$ added, $\sim 1$ million $\left(\sim 209 \pm 100\right.$ cells $\left./ \mathrm{mm}^{2}\right)$ were able to settle and adhere within the first $2 \mathrm{~h}$ (Figure 4). Not all diatoms land on the raphe (which functions in adhesion and motility), and those that do not are able to reposition within 30-90 s for firm initial adhesion (Wetherbee et al., 1998). This indicates that the biofilm would sufficiently adhere within minutes, and that $2 \mathrm{~h}$ allowed before counting was adequate as a measure of initial settlement. Any irradiated treatment densities that were below this initial input level would be counted as a removal of cells, while higher levels would be counted as growth. The treatment controls represented the ability of the diatoms to proliferate with no UV treatment and indicated the population growth from the initial cell input. Comparing irradiated to both control and initial numbers enabled inhibition of reproduction and survival to be determined.

Control densities indicated population growth over time with increases of 257, 277, 551, 500, and $425 \%$ over the following 1, 2, 3,4 , and 5 days, respectively. Irradiated tiles showed a reduction of $35,57,93,83,99$, and $98 \%$, respectively, compared to initial settlement. Compared to the growth that accrued on the controls, there were, respectively, 35, 87, 98, 98, 99, and 99\% fewer cells on the irradiated tiles (Figure 5).

Kruskal-Wallis and Wilcoxon pairwise tests were used for statistical analysis as data did not conform to assumptions of normality and equal variance after transformation. All doses resulted in a significant difference between the initial settlement, controls, and irradiated tiles (Figure 4).

\section{Effect of Duty Cycling}

Interval experiments were run for $48 \mathrm{~h}$ in periods of $20 \mathrm{~min}$, allowing 144 duty cycles. Fluences were determined as $9.35,4.68$, $2.34,0.94$, and $0.47 \mathrm{~J} / \mathrm{cm}^{2}$ for each respective duty cycle of $10: 10$, 5:15, 2.50:17.50, 1:19, and 0.50:19.50 (irradiated: no irradiance).

The control treatments indicated a mean ( \pm SD) diatom settlement of $1,352 \pm 450$ cells $/ \mathrm{mm}^{2}$, which was $989 \%$ higher than the initial cell input. Settlement differed significantly from the respective controls in all irradiance duty cycles $P<0.05$ (Figure 6). Cell densities on irradiated tiles were reduced by $94,90,95,85$, and $78 \%$ of control tiles for the 10:10, 05:15, 02.50:17.50, 01:19, and 0.50:19.50 (irradiated: no irradiance) duty cycles, respectively. Duty cycles of 10:10, 05:15, and 02.50:17.50 had reductions of 67,49 , and $58 \%$, respectively when irradiated tiles were compared to the initial settlement, whereas 01:19 and 0.50:19.50 had 19 and 24\% growth, respectively. The point at which growth was inhibited, and reduction below initial input density observed, was between 0.94 and $2.34 \mathrm{~J} / \mathrm{cm}^{2}$ (Figure 7).

\section{Effect of Voltage Changes}

Voltage experiments were run to allow varying irradiance (Figure 7 and Supplementary Table 1). All voltages indicated significant differences between control, initial, and irradiated samples (Figure 8). Low voltage irradiances resulted in diatom growth of 8,74 , and $285 \%$, respectively, compared to the initial 


\section{$\rightarrow \mathrm{A} \rightarrow \mathrm{B} \rightarrow$ Average}

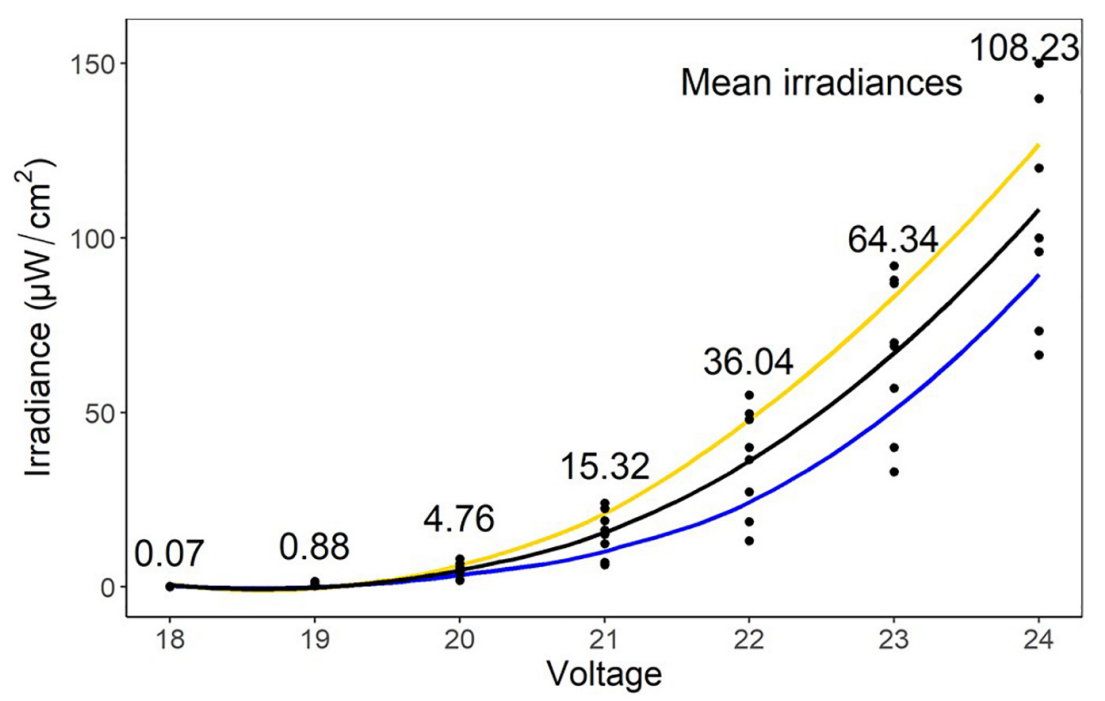

FIGURE 3 | Mean irradiances of eight LEDs embedded in two tiles (A,B) at varying voltages (18-24 V). These gave fluence values over $48 \mathrm{~h}$ of $0.01,0.15$, 0.82 , $2.65,6.23,11.12$, and $18.70 \mathrm{~J} / \mathrm{cm}^{2}$, respectively.

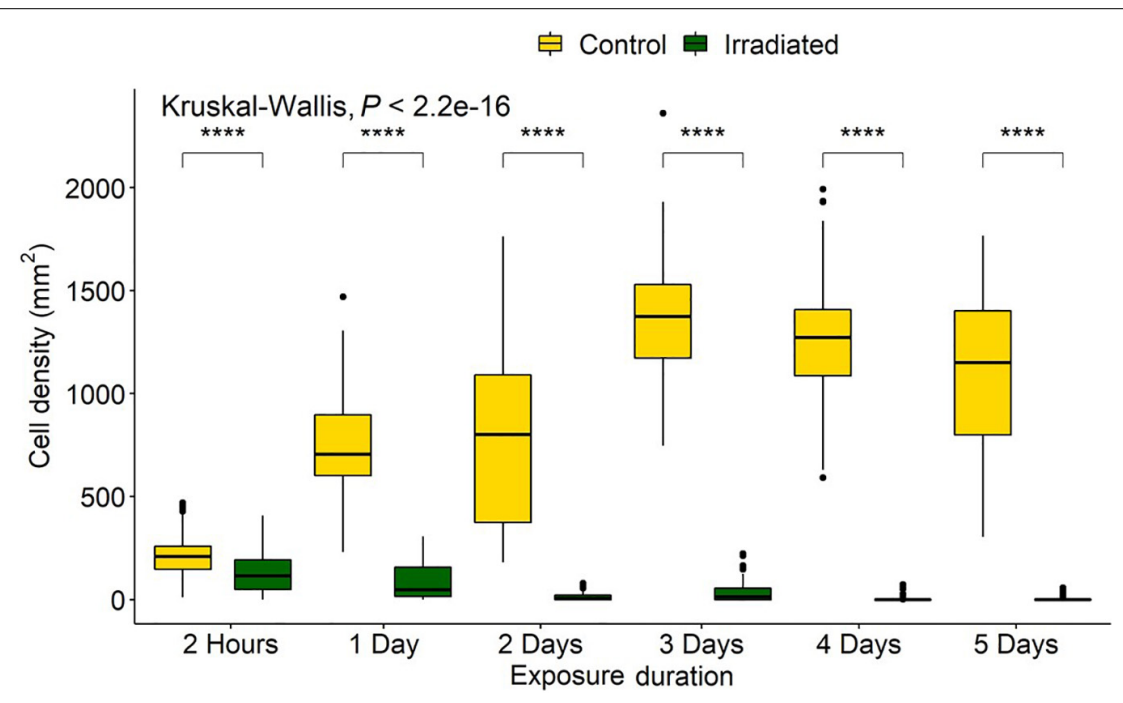

FIGURE 4 | Navicula incerta densities after UV irradiance over varying periods. Durations of $2 \mathrm{~h}, 1,2,3,4$, and 5 days produced fluences of 0.78, 9.35, 18.70,

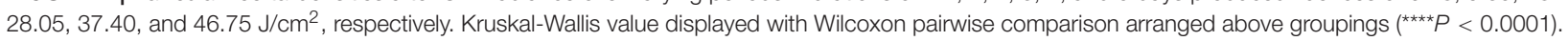

density for 18,19 , and $20 \mathrm{~V}$. Significant reductions of 52, 70, 89 , and $92 \%$ were also seen in the 21-, 22-, 23-, and $24-\mathrm{V}$ treatments compared to the initial input. All voltages resulted in significantly lower densities (cell counts) than the growth controls, with one-volt increases from 18 to $24 \mathrm{~V}$ having 20, $31,69,88,92,97.5$, and 98\% lower densities, respectively. The intersect where the irradiated cell densities overlapped with the initial cell densities was between 20 and $21 \mathrm{~V}$. This was between 0.82 and $2.65 \mathrm{~J} / \mathrm{cm}^{2}$ and represents a threshold of fluence to halt growth and, above this level, to initiate removal (Figure 9).

\section{Comparisons at High and Low Dosages}

Fluence is reported to have the same biological effect regardless of the method of delivery (Bunsen and Roscoe, 1863). Therefore, the three methods discussed previously should have resulted in reproducible reductions in diatom cell counts, if doses were the same (Sommer et al., 1996, 1998). High and low fluence groups were identified based on doses across the three experimental procedures. A low fluence of $0.78-0.94 \mathrm{~J} / \mathrm{cm}^{2}$ included the $2 \mathrm{~h}, 20 \mathrm{~V}$, and 1:19 duty cycle samples, and a high fluence of 9.35-11.12 J/cm ${ }^{2}$ included the 1 day, $23 \mathrm{~V}$, and 10:10 duty cycle samples. 


\section{$\rightarrow$ Control $\rightarrow$ Irradiated}

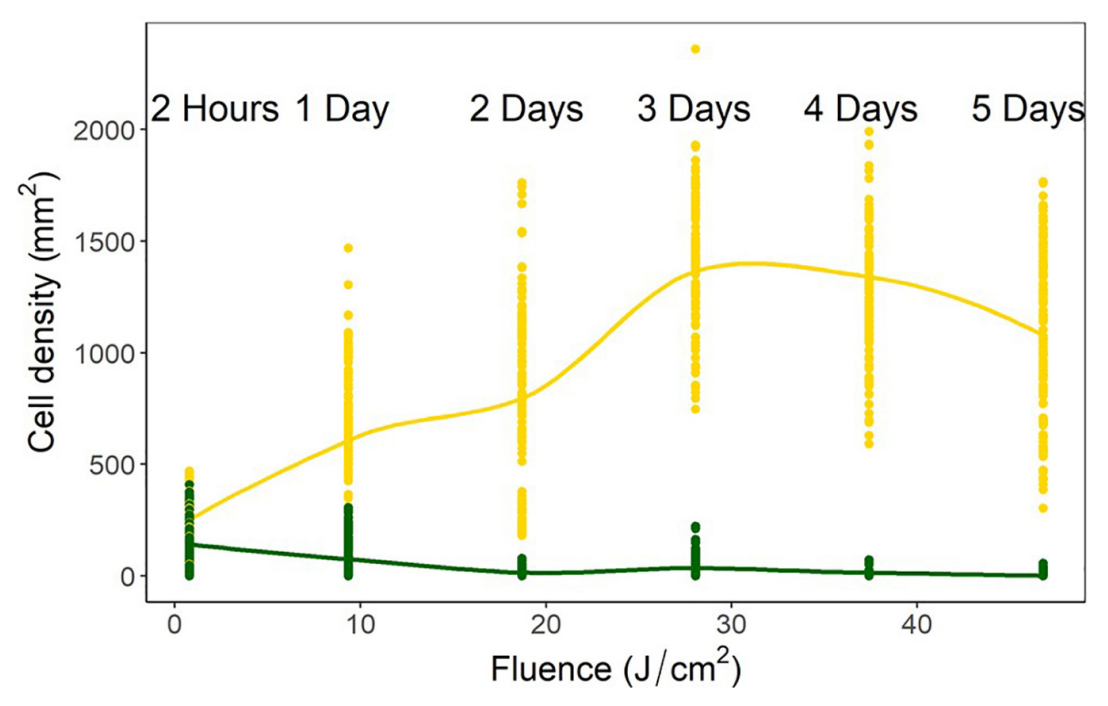

FIGURE 5 | Navicula incerta abundance after UV irradiance over varying periods with respective fluences. Durations of 2 h, 1, 2, 3, 4, and 5 days produced fluences of $0.78,9.35,18.70,28.05,37.40$, and $46.75 \mathrm{~J} / \mathrm{cm}^{2}$, respectively.

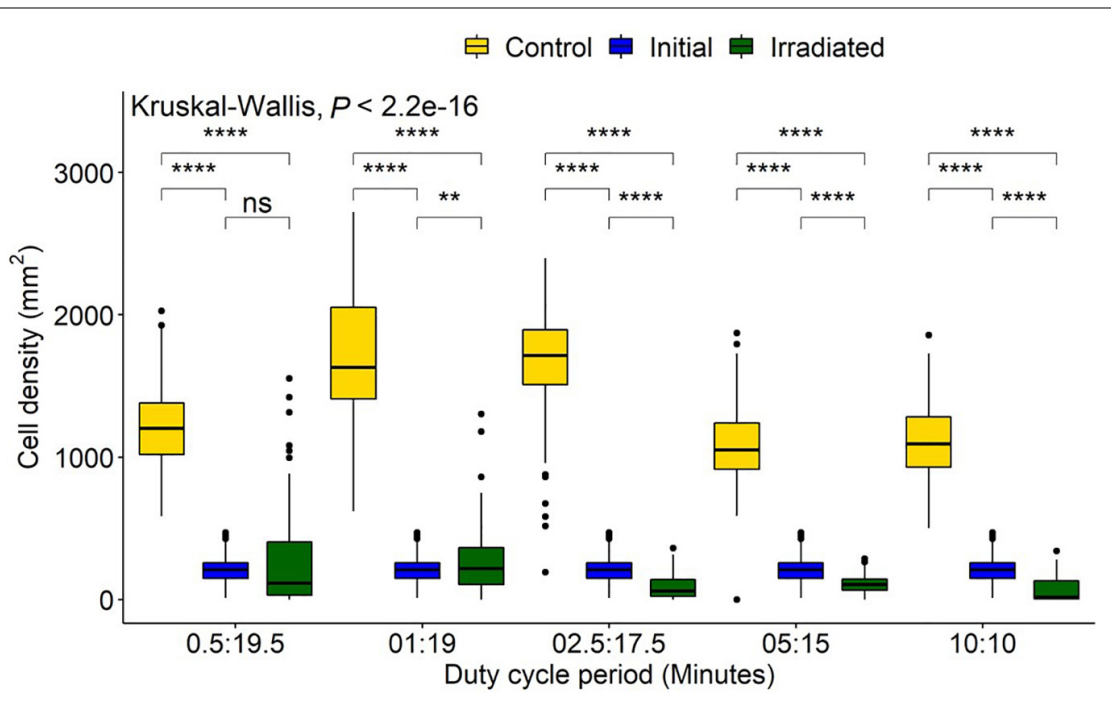

FIGURE 6 | Navicula incerta abundance after UV irradiance over varying duty cycles. Duty cycling periods display minutes in which the UV light was turned on to minutes it was turned off (On:Off). Fluences were determined as 0.47, 0.94, 2.34, 4.68, and 9.35 J/cm² for each respective duty cycle 0.50:19.50, 1:19, 2.50:17.50, 5:15, and 10:10 (irradiated: no irradiance). Significant differences indicated via Wilcoxon pairwise comparison above groupings (ns, no significance, ${ }^{\star \star} P<0.01$, $\star \star \star \star ~ P<0.0001)$.

There were no significant differences in cell densities between the $20 \mathrm{~V}$ and the 1:19 duty cycle method, however, the 2-h exposure was significantly more effective $(P<0.05)$. High fluence samples indicated that all treatment methods were significantly different from each other $(P<0.05)$, with $23 \mathrm{~V}$ having the highest removal and 1 day having the lowest removal (Figure 10).

\section{Determination of Thresholds}

The dose required to produce a 1 log reduction (lethal dose to achieve $90 \%$ cell reduction $-\mathrm{LD}_{90}$ ) below initial densities was determined via GLM using predictive analysis based on the count data. Doses were compared separately by experiment and comprehensively by removing all control data, other than the initial settlement, and comparing irradiated data against the initial data. Only data that were below the initial density level were included as densities above this indicated growth and would produce predictions based on an inflated density. The duration experiment indicated that a fluence of $42 \mathrm{~J} / \mathrm{cm}^{2}$, with a range from 35 to $52 \mathrm{~J} / \mathrm{cm}^{2}$, would be required for a $90 \%$ reduction in diatom cell density (Figure 11). The pulsing data revealed 


\section{$\rightarrow$ Control $\rightarrow$ Initial $\rightarrow$ Irradiated}

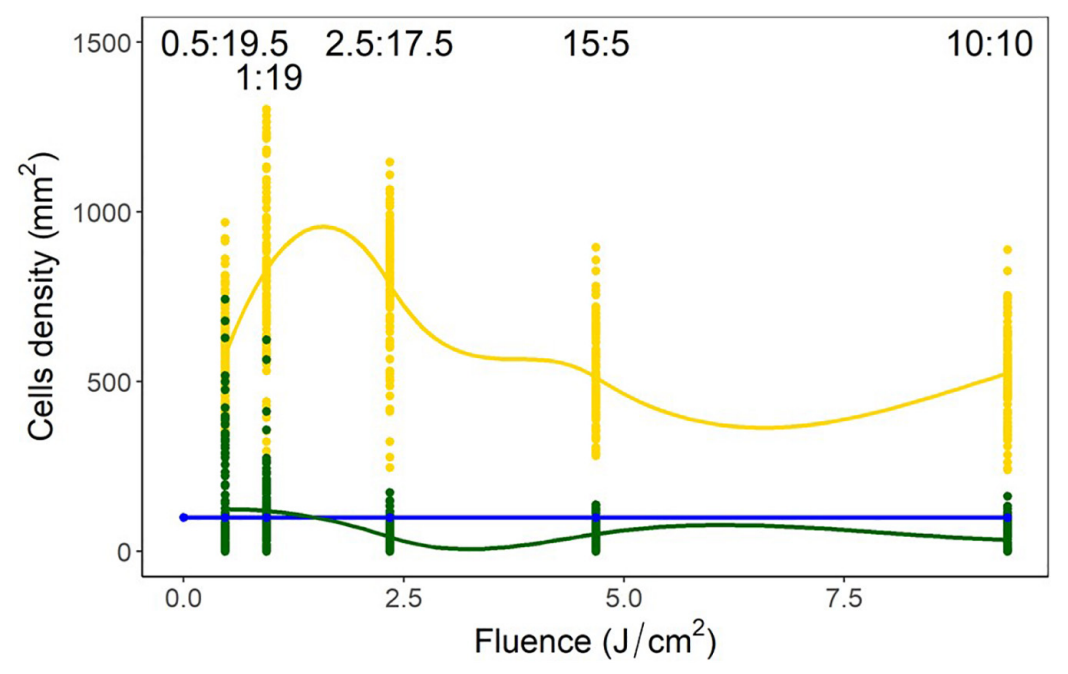

FIGURE 7 | Navicula incerta density and range after UV irradiance over varying duty cycles with respective irradiance dosages. Duty cycling periods display minutes in which the UV light was turned on to minutes it was turned off (On:Off). Fluence dosages were determined as 0.47, 0.94, 2.34, 4.68, and 9.35 J/cm² for each respective duty cycle 0.50:19.50, 1:19, 2.50:17.50, 5:15, and 10:10 (irradiated: no irradiance). Irradiated and initial intercept point (between 0.94 and 2.34 J/cm²) indicates the fluence required to reduce density below initial levels.

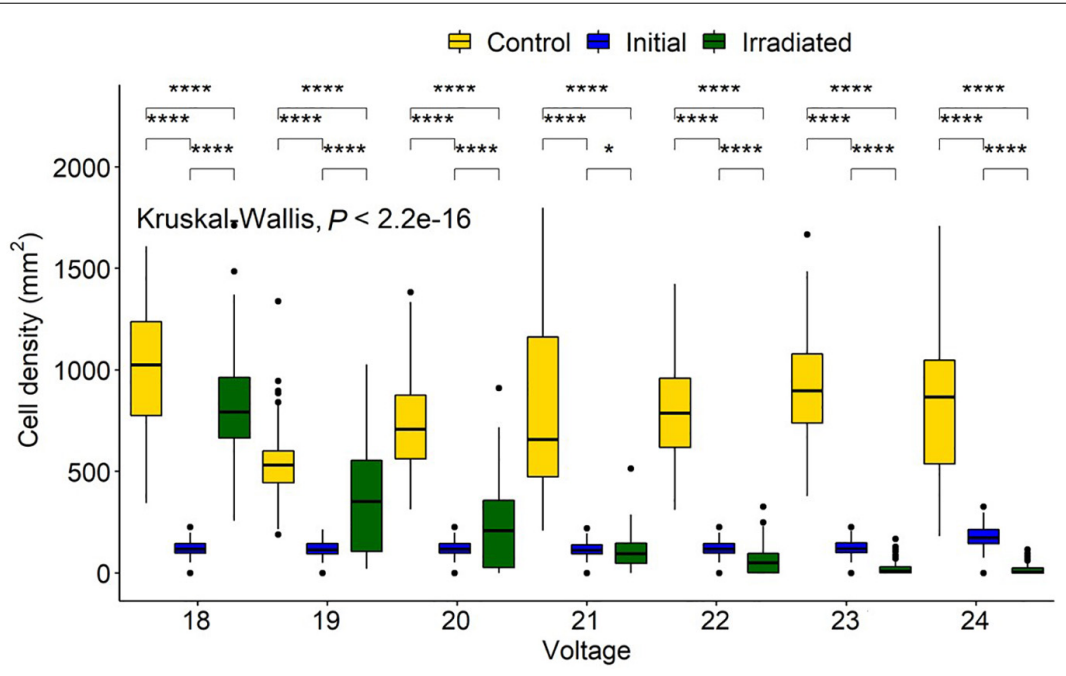

FIGURE 8 | Navicula incerta abundance and range after UV irradiance over varying voltages. Kruskal-Wallis value displayed with Wilcoxon pairwise comparison ranged above groupings $\left({ }^{\star} P<0.05,{ }^{* \star \star *} P<0.0001\right)$.

increased cell densities in 0.5:19.5 and 01:19 duty cycles and these were thus removed from GLM. Modeling indicated that a fluence of $20 \mathrm{~J} / \mathrm{cm}^{2}$, with a range from 12 to $65 \mathrm{~J} / \mathrm{cm}^{2}$, would be required for $90 \%$ diatom removal. The voltage experiment indicated that cell numbers increased in the 18-20 V treatments, which were, therefore, not included in the predictive analysis. The $\mathrm{LD}_{90}$ of the voltage experiments was a fluence of $21 \mathrm{~J} / \mathrm{cm}^{2}$ with a range of $17-28 \mathrm{~J} / \mathrm{cm}^{2}$. The comprehensive $\mathrm{LD}_{90}$ was predicted to be $25 \mathrm{~J} / \mathrm{cm}^{2}$ with a range from 19 to $36 \mathrm{~J} / \mathrm{cm}^{2}$. All four data sets produced different $\mathrm{LD}_{90} \mathrm{~s}$ and were indicative of variation between irradiance delivery method and effect. The $\mathrm{LD}_{90}$ was predicted to be between 20 and $42 \mathrm{~J} / \mathrm{cm}^{2}$, with an overall range of $12-65 \mathrm{~J} / \mathrm{cm}^{2}$.

\section{DISCUSSION}

UV treatment is an effective form of sterilization used across diverse industries (Shaban et al., 1997; Tree et al., 1997; Bintsis et al., 2000; Shaw et al., 2008; Winward et al., 2008). The present results indicate the potential of UV treatment for control of biofouling of surfaces within the marine environment. In 


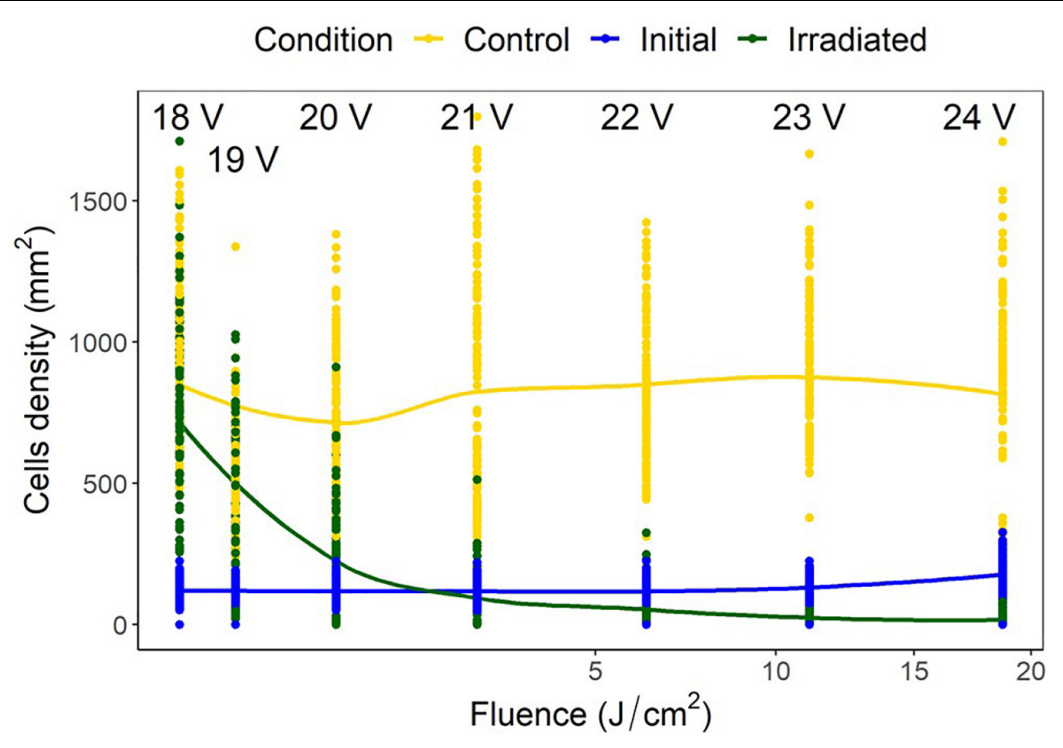

FIGURE 9 | Navicula incerta cell densities and ranges at different voltages, with the corresponding fluence on the $x$ axis. Predictive generalized linear modeling indicated the intercept between irradiated density and initial density to be between 20 and 21 volts $\left(0.82-2.65 \mathrm{~J} / \mathrm{cm}^{2}\right)$.

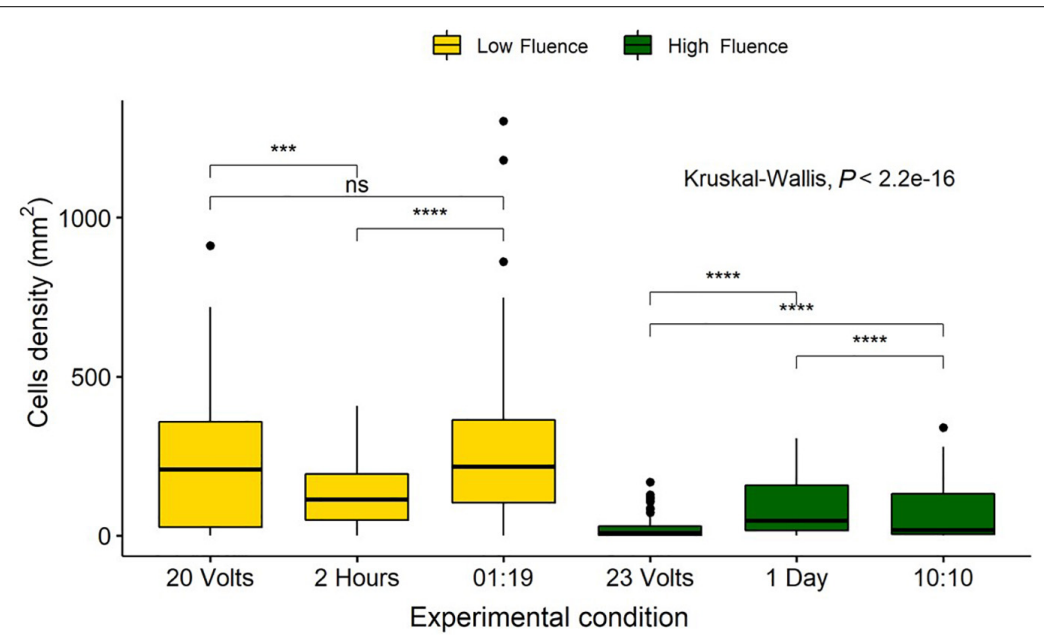

FIGURE 10 | Comparison of Navicula incerta cell densities remaining on the surface after low and high irradiance exposures. Low fluence grouped based on fluence of $0.82,0.78$, and $0.94 \mathrm{~J} / \mathrm{cm}^{2}$ for 20 volts, $2 \mathrm{~h}$, and a $01: 19$ duty cycle, respectively. High fluence grouped based on fluence of $11.12,9.35$, and $9.35 \mathrm{~J} / \mathrm{cm}^{2}$ for 23 volts, 1 day, and a 10:10 duty cycle, respectively. Kruskal-Wallis value displayed with Wilcoxon pairwise comparison arranged above groupings (ns, not significant, $\left.{ }^{\star \star \star} P<0.001,{ }^{\star \star \star \star} P<0.0001\right)$.

the experiments conducted in our study, all diatom (Navicula incerta) samples, even those exposed to low fluences $(0.01,0.47$, and $0.78 \mathrm{~J} / \mathrm{cm}^{2}$ ), demonstrated a significant reduction in densities when compared to control counts. The suppression of growth at the lowest fluence $\left(<0.78 \mathrm{~J} / \mathrm{cm}^{2}\right)$, combined with reduced cell densities above this level, highlights the efficacy of UV sterilization for biofouling control.

\section{Effect of Duration of Irradiance}

This study determined that diatom densities, compared to initial settlement, were impacted in all UV treatment durations. Cell densities in the controls (non-irradiated) increased above the initial settlement (after $2 \mathrm{~h}$ ) establishing the ability of $N$. incerta to grow within the experimental conditions. Cell densities above the initial input, but below the experimental control cell densities, suggested a negative impact of UV treatment on cell proliferation, but biofilm growth was not entirely prevented. Cell densities, which were similar to initial densities after irradiance, implied a stop to cell division and an equilibrium between the repair mechanisms and the exposure dosage. Finally, when cell counts were lower than the initial cell count, following irradiance at fluences from 0.78 to $46.75 \mathrm{~J} / \mathrm{cm}^{2}$, the implication is that cell division stopped, and repair mechanisms could not keep pace with the damage caused by UV exposure. By 

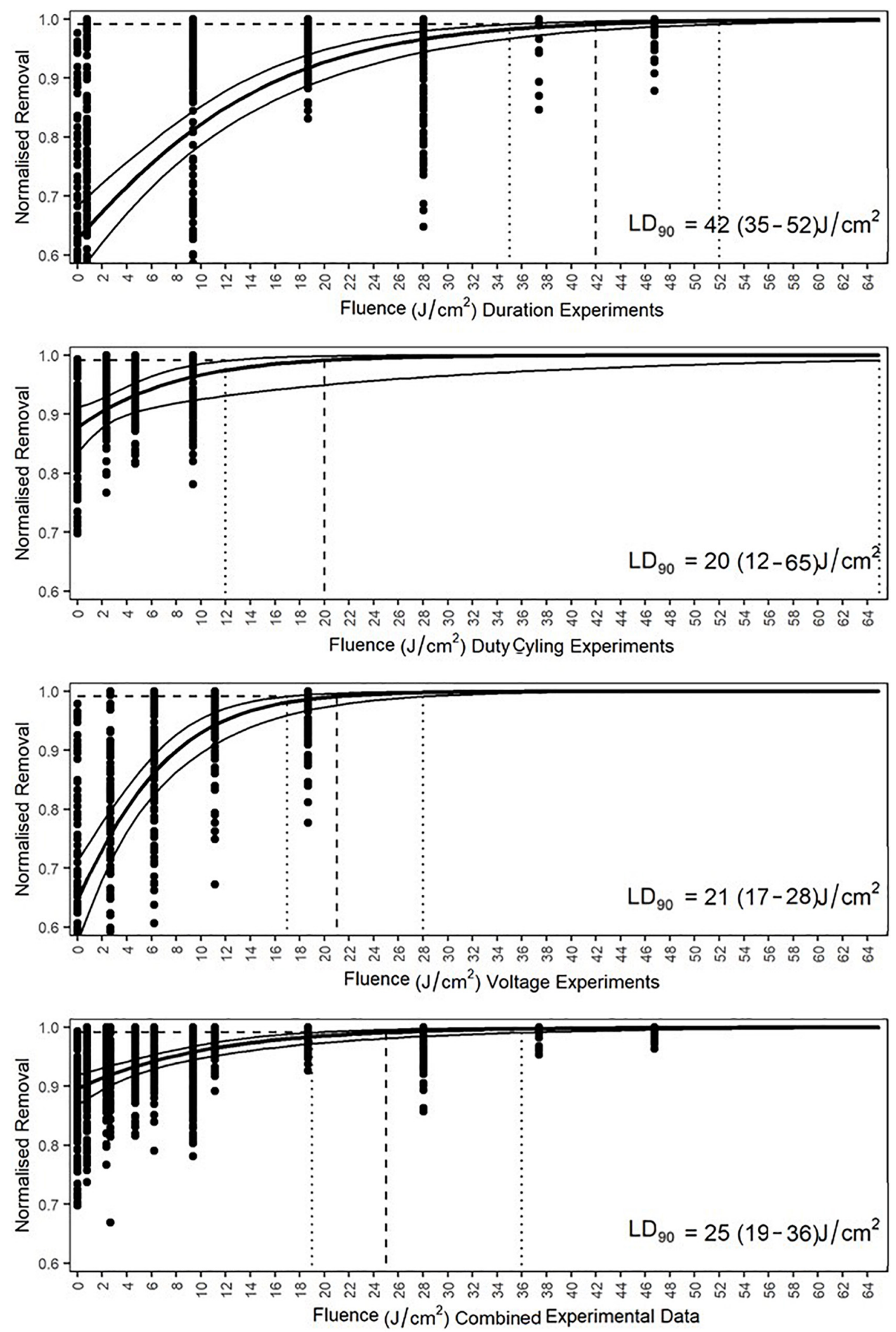

FIGURE 11 | Generalized linear model predicted lethal fluences, expressed as LD90, of each experiment and the combined data to obtain a 90\% reduction in cell density of Navicula incerta below the initial cell density. Dashed lines intercept at the LD90. The 95\% confidence interval ranges are indicated by the vertical dotted lines with the values in parentheses. 
whatever mechanism, death and/or detachment, cells were lost from the surface.

The lowest fluences produced a reduction in cell densities, although a $1 \log$ reduction compared to the initial settlement was only observed after 2 days of irradiance, equivalent to $18.70 \mathrm{~J} / \mathrm{cm}^{2}$ (Figure 5). After 4 days of irradiance, cell density was nearly 3 log lower than the control, suggesting that continuous irradiance was extremely effective, even at low fluence. This implied that fluence sufficient to negate growth and induce removal (i.e., above $18.7 \mathrm{~J} / \mathrm{cm}^{2}$ ), could be achieved to meet performance specifications required for antifouling approval by MIL-PRF-24647C and the European Chemical Agency (European Chemicals Agency, 2014; ECHA/EFSA, 2017). However, the methods required by the European Chemical Agency and MIL-PRF-24647C were mainly developed with chemical biocides in mind. There is currently no EU regulation under which an UV-based antifouling method could be appropriately certified (ECHA/EFSA, 2017).

\section{Effect of Voltage}

Voltage supply directly affected the irradiance of the LEDs with changes of a single voltage unit causing a reduction in irradiance (Figure 3). This had a substantial effect on the diatoms (Figure 9). Growth at the lowest voltages (18-20 V) was influenced by only small changes in voltage. Higher voltage supply (21-24 V) reduced cell density below the initial count, indicating a potential effective level for prevention of biofilm growth. This threshold is important for the optimized design of UV-B/C LED systems for biofouling control, though additional target fouling species need to be tested. An effective antifouling level (the required irradiance for preventing the growth of organisms on a surface) has been predicted to be $1 \mu \mathrm{W} / \mathrm{cm}^{2}$ for UV-based antifouling systems (Piola et al., 2016). The fluence supplied to the tile surface in the current study had an average peak value which was 5.77 times higher than the predicted value at the recommended operating voltage $(24 \mathrm{~V})$, and a total UV-B/C fluence that was 109 times greater. Based on spectroradiometer readings, $19 \mathrm{~V}$ (Figure 3) supplied the closest irradiance for comparison to the reported level. Piola et al. (2016) stated that the level could be even lower than $1 \mu \mathrm{W} / \mathrm{cm}^{2}$ and, for the current study, the irradiance threshold for $N$. incerta was validated as below $0.7 \mu \mathrm{W} / \mathrm{cm}^{2}$. Although, as indicated by the intercept point in Figure 9, to achieve a reduction below initial cell density, a fluence between $4.76-15.32 \mathrm{~J} / \mathrm{cm}^{2}$ (between 20 and $21 \mathrm{~V}$ ) would be required. Determining whether this can translate into the natural environment is imperative, as cultured organisms are known to be less resilient than their wild-type counterparts (Falciatore et al., 2020). Dissolved organic matter within the water can also impede UV treatment efficacy (Georgiades et al., 2021). Moreover, diatoms are just one component of a complex biofouling community. The extracellular polymeric substances secreted by diatoms, and the silicate structures left behind by dead cells, could attract and protect further colonizers. Wild-type resilience and population interactions may cause the effective level to differ from that currently indicated.

\section{Effect of Duty Cycling}

Developing UV as an antifouling strategy will require the method to meet some design criteria, one of which is prolonged efficacy with minimal maintenance. The manufacturers' specifications for the half-life (irradiance output) of the LEDs used in this study was $10,000 \mathrm{~h}$ (1.14 years), at constant irradiance. Visible light LEDs, on the other hand, can exceed 100,000 h of use and UV LED life expectancy will likely improve as technology develops (Muramoto et al., 2014). Several years of fouling protection under various conditions will be required to make the integration of UV LEDs appealing to the shipping industry.

Duty cycles were compared to explore lengthening the longevity of the LEDs. Outcomes demonstrated that even the shortest duty cycle of $2.5 \%$ could inhibit biofilm growth. Control tiles of the 02.50:17.50 and 01:19 duty cycles had higher diatom densities than the other duty cycle controls $(P<0.05)$. This apparent anomaly may be explained by the use of a new stock of $\mathrm{F} / 2$ growth medium, or small variations in cell density at the start of the experiment. This higher density may have allowed some variation within the irradiated samples. Since the same stock was used for both control and irradiated exposures, however, the differences may be compared.

A $12.5 \%$ duty cycle would be required to prevent growth and effectively reduce fouling. At the lower $2.5 \%$ cycle, longevity of the LEDs could be increased to 45.6 years, whilst at $12.5 \%$ cycling, 9.2 years could be achieved. Duty cycling of $0.01 \%$ ( $1 \mathrm{~min} /$ week) has been reported by Richard et al. (2021) to have a significant impact, however, for full macrofouling prevention, a duty cycle of $0.69 \%$ (10 min per day) was required. Rates as low as these could see effective antifouling via UV lasting the entirety of a vessel's lifespan. Differences in the effectiveness of the duty cycling between this study and the study by Richard et al. (2021) could be due to the different light sources used. Richard et al. (2021) used a $25 \mathrm{~W}$ Aqua UVC (254 nm) lamp rather than LEDs. This provided different irradiances than the current study and recorded an intensity of $1.31 \mu \mathrm{W} / \mathrm{cm}^{2}$ at a peak wavelength of $254 \mathrm{~nm}$ rather than the $281 \mathrm{~nm}$ used herein. As biological impact is dose-dependent, a threshold would be advantageous in isolating specific duty cycles from individual light supplies.

\section{Comparisons at High and Low Doses}

Variation in dose and biological impact were comparable between the three methods of irradiance delivery used in the current study and provided effects of low and high fluence on cell density. Low fluence experiments included the 2-h experiment, which resulted in lower cell densities than the other methods. The lower cell density in the 2-h treatment, as opposed to $20 \mathrm{~V}$ and the 01:19 duty cycle, could be due to the fluence being below an effective inactivation level. This would enable the diatoms to proliferate during the 48-h experiment. According to the Bunsen-Roscoe reciprocity law (Bunsen and Roscoe, 1863), the total photochemical dose absorbed by an organism will have the same effect regardless of varying irradiance and/or exposure durations. Supporting evidence was discussed by Sommer et al. (1998) who found that a microbiocidal dose of $400 \mathrm{~J} / \mathrm{m}^{2}$ was required for a 4 -log bacterial reduction regardless of delivery 
intensity. Sommer et al. (1996) indicated that a low intensity and longer exposure duration was more effective at inactivation than short high irradiance on eukaryotic yeast cells. Escherichia coli and bacteriophages have displayed the opposite, reducing more over shorter durations at higher intensities (Sommer et al., 1998; Werschkun et al., 2012). UV damage is not described as being time dependent and is associated with the overall dose. However, diatoms require time to complete biological processes such as division and growth. Therefore, the biological processes may have counteracted some of the damage and be accountable for the differences. The densities may have been relatable if the 2$h$ experiment had the UV turned off and the diatoms left to grow for a further $46 \mathrm{~h}$.

The longer experimental duration could explain why the high exposure $23 \mathrm{~V}$ experiment, in high fluence samples, had a lower cell density than the 1 day and duty cycle doses. If the irradiance is above an effective threshold for a longer time, then there would be more time for the population to reduce in number. This could explain why the $23 \mathrm{~V}$ method was significantly more effective than its similar dosage counterparts (Figure 10). The variance between sample counts in the duty cycle and the 1day method was large, whereas the $23 \mathrm{~V}$ experiment had minor variance. This may indicate greater resilience during the pulsed method and could also result from repair and recovery during LED downtime. With regard to the 1-day experiment, the shorter duration may have different effects on diatoms of different sizes, as described by van de Waal and Litchman (2020). This could explain the variability within the counts and the deviation from the full exposure. The current results (Figure 10) contradict the Bunsen-Roscoe reciprocity law as similar irradiances produced significantly different effects. For $N$. incerta short, high irradiance treatments were more effective at inactivation than longer, lower intensity treatments which may indicate that biological factors can alter the overall outcome from a prolonged exposure.

It is important to consider that both high and low fluence had some variability and that the exact dose was not the same in all cases. The high doses, from the comprehensive analysis, had identical duty cycle and 1-day doses $\left(9.35 \mathrm{~J} / \mathrm{cm}^{2}\right)$, however, the $23 \mathrm{~V}$ dose was $1.77 \mathrm{~J} / \mathrm{cm}^{2}$ higher than these and could explain the lower cell density present within that treatment. Additionally, the low fluences were conducted with no two identical measures delivered, although they only varied by $0.16 \mathrm{~J} / \mathrm{cm}^{2}$ from highest to lowest. To clarify a fluence effect without variation, a repeat of the experiment with exact dose comparisons of the three different treatment methods would be necessary to determine if the small irradiance discrepancy was important.

The data in the current study suggest that the BunsenRoscoe law does not allow for interacting biological factors. Diatoms can self-repair photoactive lesions via excision repair mechanisms using photosynthetic light (De Tommasi et al., 2018). This enables them to excise the lesions from the DNA and combat the overall damage. A high intensity could overwhelm an organisms' repair mechanisms and a heavily outweighed system would be expected to inactivate quicker than a neutrally balanced or minimally overcome system. Additionally, if there was no interacting repair mechanism, the organisms would still be limited due to their quantum yield (Braslavsky, 2007).
Organisms can only absorb a certain number of photons in a set period before reaching their maximum quantum yield, after which photons that the organism is exposed to become surplus (Li et al., 2006, 2010). Like enzyme reactions, there would be a limit to the reactions that could take place at any given time.

\section{Threshold Analysis}

The interaction between growth and density provides insight into a potential threshold of effect. To prevent growth, but not reduce below initial density, the threshold was determined to be between 0.01 and $0.78 \mathrm{~J} / \mathrm{cm}^{2}$. For densities to be reduced below the initial input levels, a threshold point between 0.78 and $2.65 \mathrm{~J} / \mathrm{cm}^{2}$ would be required. This is similar to the level reported by Piola et al. (2016). Using the densities and fluences from all three experiments and a combination of all the data, $\mathrm{LD}_{90}$ s were calculated, which suggest a predicted dose to reduce the initial input densities by $90 \%$ (Raikow et al., 2007). According to the Bunsen-Roscoe reciprocity law $\mathrm{LD}_{90}$ fluences should be the same regardless of methodology, however these were observed to vary in the current study. Cell density counts from pulsing (Supplementary Table 1) indicated that supplied irradiance doses did not reduce initial levels below 90\%, but duration and voltage methodologies both indicated that $18.7 \mathrm{~J} / \mathrm{cm}^{2}$ produced over $90 \%$ removal. The predicted $\mathrm{LD}_{90}$ for guaranteed effect ranged from 12 to $65 \mathrm{~J} / \mathrm{cm}^{2}$ depending on delivery method, and $25 \mathrm{~J} / \mathrm{cm}^{2}$ when averaged across all of the data. Experiments with diatoms were conducted using a high nutrient growth medium $(F / 2)$, these nutrient concentrations are not expected to be encountered in the natural environment. Biofilm growth would therefore be slower than observed in laboratory conditions that are optimized for growth. Accordingly, a lower dose may be required for wild type removal. However, as both controls and irradiated experiments used the same medium, the results within the study are comparable. An adaption for more accurate thresholds would require a comparison between this study and field experiments. The predicted threshold for $90 \%$ removal, based on all data, was $25 \mathrm{~J} / \mathrm{cm}^{2}$. However, this is likely to be a conservative estimate when the fluences and their respective cell densities are compared. Duration and voltage treatments had $>88 \%$ removal at 18.7 and $11.12 \mathrm{~J} / \mathrm{cm}^{2}$, respectively, which is considerably lower than the predicted value. The latter could have been impacted by the variability in densities and the pulsing not achieving 90\% removal, which could explain why the threshold value was elevated. Adhering to an elevated fluence, similar to the conservative prediction, should result in effective antifouling prevention and removal but other factors that affect UV efficacy, not currently investigated, would need to be considered.

\section{CONCLUSION}

The effectiveness of UV-B/C for antifouling has been confirmed using a technology (LEDs) that could plausibly be incorporated using a cladding system. The effective levels determined by duty cycling could allow longer lifespans of LED equipment, and longer intervals between repair or replacement. Lower voltages of delivery would lower LED strain and could also 
prolong longevity. By determining effective thresholds and doses, equipment can be developed to efficiently meet standards and protocols for the approval of $\mathrm{UV} \mathrm{B/C}$ integration as an antifouling system. Exploration of ecosystem thresholds, under a range of field conditions (including non-target effects), is required to fine-tune this threshold level.

\section{DATA AVAILABILITY STATEMENT}

The datasets presented in this study can be found in online repositories. The names of the repository/repositories and accession number(s) can be found below: Newcastle University Data Repository; doi: 10.25405/data.ncl.16811044.

\section{AUTHOR CONTRIBUTIONS}

PW was the primary researcher undertaking method development, experimentation, statistical analysis, figure production, and document scripting. KR was the technical lead aiding in method development and equipment production. AC and NA were in supervisory roles aiding in scientific theory and manuscript development. PD and JP aided in manuscript editing and technical partnering which drove the projects progress. All

\section{REFERENCES}

Almeida, E., Diamantino, T. C., and de Sousa, O. (2007). Marine paints: the particular case of antifouling paints. Prog. Organ. Coatings 59, 2-20. doi: 10. 1016/j.porgcoat.2007.01.017

Bannister, J., Sievers, M., Bush, F., and Bloecher, N. (2019). Biofouling in marine aquaculture: a review of recent research and developments. Biofouling 35, 631-648. doi: 10.1080/08927014.2019.1640214

Bintsis, T., Litopoulou-Tzanetaki, E., and Robinson, R. K. (2000). Existing and potential applications of ultraviolet light in the food industry - a critical review. J. Sci. Food Agriculture 80, 637-645.

Bloecher, N., Olsen, Y., and Guenther, J. (2013). Variability of biofouling communities on fish cage nets: a 1-year field study at a Norwegian salmon farm. Aquaculture 41, 302-309. doi: 10.1016/j.aquaculture.2013.09.025

Braslavsky, S. E. (2007). Glossary of terms used in photochemistry 3rd edition: (IUPAC Recommendations 2006). Pure Appl. Chem. 79, 293-465. doi: 10.1351/ pac200779030293

Bugbee, B. (2017). "Economics of LED lighting BT," in Light Emitting Diodes for Agriculture: Smart Lighting, (ed.) S. Dutta Gupta (Singapore: Springer), 81-99

Bunsen, R. W., and Roscoe, H. E. (1863). III. Photochemical researches.-Part V. on the measurement of the chemical action of direct and diffuse sunlight. Proc. R. Soc. London 12, 306-312.

Cacabelos, E., Ramalhosa, P., Canning-Clode, J., Troncoso, J. S., Olabarria, C., Delgado, C., et al. (2020). The role of biofilms developed under different anthropogenic pressure on recruitment of macro-invertebrates. Int. J. Mol. Sci. 21, 1-28. doi: 10.3390/ijms21062030

Callow, J. A., and Callow, M. E. (2011). Trends in the development of environmentally friendly fouling-resistant marine coatings. Nat. Commun. 2, 210-244. doi: 10.1038/ncomms1251

Callow, M. E., and Callow, J. A. (2002). Marińe biofouling: a sticky problem. Biologist 49, 10-14.

Chen, C. L., Maki, J. S., Rittschof, D., and Teo, S. L. M. (2013). Early marine bacterial biofilm on a copper-based antifouling paint. Int. Biodeterioration Biodegradation. 83, 71-76. doi: 10.1016/j.ibiod.2013.04.012 authors contributed to the article and approved the submitted version.

\section{FUNDING}

This project was primarily funded as part of the Materials for Strategic Advantage Program run by the Defence Science and Technology Laboratory (DSTL). Newcastle University and AkzoNobel subsidized funding toward laboratory and University costs.

\section{ACKNOWLEDGMENTS}

We would like to acknowledge the contributions of John Finlay for advice and aid in algae culturing in the laboratory.

\section{SUPPLEMENTARY MATERIAL}

The Supplementary Material for this article can be found online at: https://www.frontiersin.org/articles/10.3389/fmars. 2021.809011/full\#supplementary-material

Supplementary Table 1 | Experimental exposures, cell densities, and percentage differences.

Clare, A. S., Rittschof, D., Gerhart, D. J., and Maki, J. S. (1992). Molecular approaches to nontoxic antifouling. Invertebr. Reprod. Dev. 22, 67-76. doi: 10.1080/07924259.1992.9672258

Coutts, A. D. M., and Dodgshun, T. J. (2007). The nature and extent of organisms in vessel sea-chests: a protected mechanism for marine bioinvasions. Mar. Pollut. Bull. 54, 875-886. doi: 10.1016/j.marpolbul.2007.03.011

Coutts, A. D. M., and Taylor, M. D. (2004). A preliminary investigation of biosecurity risks associated with biofouling on merchant vessels in New Zealand. New Zealand J. Mar. Freshwater Res. 38, 215-229. doi: 10.1080/ 00288330.2004 .9517232

Coutts, A. D. M., Moore, K. M., and Hewitt, C. L. (2003). Ships sea-chests: an overlooked transfer mechanism for non-indigenous marine species? Mar. Pollut. Bull. 46, 1510-1513. doi: 10.1016/S0025-326X(03)00292-293

Dang, H., and Lovell, C. R. (2016). Microbial surface colonization and biofilm development in marine environments. Microbiol. Mol. Biol. Rev. 80, 91-138. doi: 10.1128/mmbr.00037-15

De Castro, M. C. T., Vance, T., Yunnie, A. L., Fileman, T. W., and Hall-Spencer, J. M. (2018). Low salinity as a biosecurity tool for minimizing biofouling on ship sea chests. Ocean Sci. 14, 661-667. doi: 10.5194/os-14-661-2018

De Tommasi, E., Congestri, R., Dardano, P., De Luca, A. C., Managò, S., Rea, I., et al. (2018). UV-shielding and wavelength conversion by centric diatom nanopatterned frustules. Sci. Rep. 8:16285. doi: 10.1038/s41598-018-34651-w

Dobretsov, S., Abed, R. M. M., and Teplitski, M. (2013). Mini-review: inhibition of biofouling by marine microorganisms. Biofouling 29, 423-441. doi: 10.1080/ 08927014.2013.776042

ECHA/EFSA (2017). Guidance on the Biocidal Products Regulation: Volume IV Environment - Assessment and Evaluation (Parts B $+C$ ). Helsinki: ECHA.

European Chemicals Agency (2014). Transitional Guidance on the Biocidal Products Regulation - Transitional Guidance on Mixture Toxicity Assessment for Biocidal Products for the Environment. Helsinki: European Chemicals Agency.

Falciatore, A., Jaubert, M., Bouly, J. P., Bailleul, B., and Mock, T. (2020). Diatom molecular research comes of age: model species for studying phytoplankton biology and diversity. Plant Cell 32, 547-572. doi: 10.1105/tpc.19. 00158 
Flemming, H. C., Murthy, P. S., Venkatesan, R., and Cooksey, K. (2009). Marine and Industrial Biofouling. Los Angeles, CA: Springer.

Georgiades, E., Kluza, D., Bates, T., Lubarsky, K., Brunton, J., Growcott, A., et al. (2020). Regulating vessel biofouling to support New Zealand's marine biosecurity system - a blue print for evidence-based decision making. Front. Mar. Sci. 7:390. doi: 10.3389/fmars.2020.00390

Georgiades, E., Scianni, C., Davidson, I., Tamburri, M. N., First, M. R., Ruiz, G., et al. (2021). The role of vessel biofouling in the translocation of marine pathogens: management considerations and challenges. Front. Mar. Sci. 8:660125. doi: 10.3389/fmars.2021.660125

Gómez-Ramírez, A. L., Enriquez-Ocaña, L. F., Miranda-Baeza, A., Cordero Esquivel, B., López-Elías, J. A., and Martínez-Córdova, L. R. (2019). Biofilmforming capacity of two benthic microalgae, Navicula incerta and Navicula sp., on three substrates (Naviculales: Naviculaceae). Rev. Biol. Trop. 67, 599-607.

Growcott, A., Kluza, D., and Georgiades, E. (2017). Review: in-water systems to reactively manage biofouling in sea chests and internal pipework. Mar. Technol. Soc. J. 51, 89-104. doi: 10.4031/MTSJ.51.2.3

Grzegorczyk, M., Pogorzelski, S. J., Pospiech, A., and Boniewicz-Szmyt, K. (2018). Monitoring of marine biofilm formation dynamics at submerged solid surfaces with multitechnique sensors. Front. Mar. Sci. 5:363. doi: 10.3389/fmars.2018. 00363

Hadfield, M. G. (2011). Biofilms and marine invertebrate larvae: what bacteria produce that larvae use to choose settlement sites. Ann. Rev. Mar. Sci. 3, 453-470. doi: 10.1146/annurev-marine-120709-142753

Hadfield, M., and Paul, V. (2001). Natural chemical cues for settlement and metamorphosis of marine-invertebrate larvae", in Marine Chemical Ecology, eds J. B. McClintock and B. J. Baker, (Boca Raton, FL: CRC Press). doi: 10.1201/ 9781420036602.ch13

Han, X., Wu, J., Zhang, X., Shi, J., Wei, J., Yang, Y., et al. (2021). Special issue on advanced corrosion-resistance materials and emerging applications. the progress on antifouling organic coating: from biocide to biomimetic surface. J. Mater. Sci. Technol. 61, 46-62. doi: 10.1016/j.jmst.2020.07.002

Hopkins, G., Davidson, I., Georgiades, E., Floerl, O., Morrisey, D., and Cahill, P. (2021). Managing biofouling on submerged static artificial structures in the marine environment - assessment of current and emerging approaches. Front. Mar. Sci. 8:759194. doi: 10.3389/fmars.2021.759194

Hunsucker, K. Z., Braga, C., Gardner, H., Jongerius, M., Hietbrink, R., Salters, B., et al. (2019). Using ultraviolet light for improved antifouling performance on ship hull coatings. Biofouling 35, 658-668. doi: 10.1080/08927014.2019. 1642334

Hunsucker, K. Z., Koka, A., Lund, G., and Swain, G. (2014). Diatom community structure on in-service cruise ship hulls. Biofouling 30, 1133-1140. doi: 10.1080/ 08927014.2014.974576

Kardela, J. H., Millichamp, I. S., Ferguson, J., Parry, A. L., Reynolds, K. J., Aldred, N., et al. (2019). Nonfreezable water and polymer swelling control the marine antifouling performance of polymers with limited hydrophilic content. ACS Appl. Mater. Interfaces 11, 29477-29489. doi: 10.1021/acsami.9b05893

Kiil, S., Dam-Johansen, K., Weinell, C. E., Pedersen, M. S., and Codolar, S. A. (2002). Dynamic simulations of a self-polishing antifouling paint exposed to seawater. J. Coat. Technol. 74, 45-54. doi: 10.1007/BF02698368

Kuffner, I. B. (2001). Effects of ultraviolet (UV) radiation on larval settlement of the reef coral Pocillopora damicornis. Mar. Ecol. Prog. Ser. 217, 251-261. doi: 10.3354/meps217251

Lejars, M., Margaillan, A., and Bressy, C. (2012). Fouling release coatings: a nontoxic alternative to biocidal antifouling coatings. Chem. Rev. 112, 43474390. doi: $10.1021 / \mathrm{cr} 200350 \mathrm{v}$

Li, C., Wang, G., Chen, K., Jia, P., Wang, L., Wang, X., et al. (2020). Analysis of removing barnacles attached on rough substrate with cleaning robot. J. Mar. Sci. Eng. 8:569. doi: 10.3390/JMSE8080569

Li, J., Liu, Z., Tan, C., Guo, X., Wang, L., Sancar, A., et al. (2010). Dynamics and mechanism of repair of ultraviolet-induced (6-4) photoproduct by photolyase. Nature 466, 887-890. doi: 10.1038/nature09192

Li, J., Uchida, T., Todo, T., and Kitagawa, T. (2006). Similarities and differences between cyclobutane pyrimidine dimer photolyase and (6-4) photolyase as revealed by resonance Raman spectroscopy: electron transfer from the FAD cofactor to ultraviolet-damaged DNA. J. Biol. Chem. 281, 25551-25559. doi: 10.1074/jbc.M604483200
Liu, M., Li, S., Wang, H., Jiang, R., and Zhou, X. (2021). Research progress of environmentally friendly marine antifouling coatings. Polymer Chem. 12, 3702-3720. doi: 10.1039/d1py00512j

MacroTrends (2021). WTI Crude Oil Prices. Available online at: https: //www.macrotrends.net/2516/wti-crude-oil-prices-10-year-daily-chart (Accessed September 30, 2021)

Maréchal, J. P., and Hellio, C. (2009). Challenges for the development of new non-toxic antifouling solutions. Int. J. Mol. Sci. 10, 4623-4637. doi: 10.3390/ ijms10114623

Matin, A., Laoui, T., Falath, W., and Farooque, M. (2021). Fouling control in reverse osmosis for water desalination \& reuse: current practices \& emerging environment-friendly technologies. Sci. Total Environ. 765:142721. doi: 10. 1016/j.scitotenv.2020.142721

Munk, T., Kane, D., and Yebra, D. M. (2009). "The effects of corrosion and fouling on the performance of ocean-going vessels: a naval architectural perspective," in Advances in Marine Antifouling Coatings and Technologies, eds C. Hellio and D. Yebra (Sweden: World Maritime University), 148-176. doi: 10.1533/ 9781845696313.1.148

Muramoto, Y., Kimura, M., and Nouda, S. (2014). Development and future of ultraviolet light-emitting diodes: UV-LED will replace the UV lamp. Semiconductor Sci. Technol. 29:084004.

Piola, R. F., and Hopkins, G. A. (2012). Thermal treatment as a method to control transfers of invasive biofouling species via vessel sea chests. Mar. Pollut. Bull. 64, 1620-1630. doi: 10.1016/j.marpolbul.2012. 05.028

Piola, R., Salters, B., Grandison, C., Ciacic, M., and Hietbrink, R. (2016). Assessing the Use of Low Voltage UV-light Emitting Miniature LEDs for Marine Biofouling Control. St, Port Melbourne VIC: DST. DST-Group-TR-3266.

Pistone, A., Scolaro, C., and Visco, A. (2021). Mechanical properties of protective coatings against marine fouling: a review. Polymers 13:173. doi: 10.3390/ polym 13020173

Pritchard, A. M. (1988). The Economics of Fouling, in Fouling Science and Technology. Alphen aan den Rijn: Kluwer Academic Publishers. CA NATO ASI Series E.

R Core Team (2021). R: A Language and Environment for Statistical Computing. Vienna: R Core Team.

Raikow, D. F., Reid, D. F., Blatchley, E. R. III, Jacobs, G., and Landrum, P. F. (2007). Effects of proposed physical ballast tank treatments on aquatic invertebrate resting eggs. Environ. Toxicol. Chem. 26, 717-725. doi: 10.1897/06-403R.1

Railkin, A. I. (2003). Marine Biofouling: Colonization Processes and Defenses. Boca Raton, FL: CRC Press.

Richard, K. N., Hunsucker, K. Z., Gardner, H., Hickman, K., and Swain, G. (2021). The application of UVC used in synergy with surface material to prevent marine biofouling. J. Mar. Sci. Eng. 9:662. doi: 10.3390/jmse9060662

Roberts, D., Rittschof, D., Holm, E., and Schmidt, A. R. (1991). Factors influencing initial larval settlement: temporal, spatial and surface molecular components. J. Exp. Mar. Biol. Ecol. 150, 203-221. doi: 10.1016/0022-0981(91)90068-9 0068

Salta, M., Wharton, J. A., Blache, Y., Stokes, K. R., and Briand, J. F. (2013). Marine biofilms on artificial surfaces: structure and dynamics. Environ. Microbiol. 15, 2879-2893. doi: 10.1111/1462-2920.12186

Scheer, B. T. (1945). The development of marine fouling communities. Biol. Bull. $89,103-121$.

Schreier, W. J., Kubon, J., Regner, N., Haiser, K., Schrader, T. E., Zinth, W., et al. (2009). Thymine dimerization in DNA model systems: cyclobutane photolesion is predominantly formed via the singlet channel. J. Am. Chem. Soc. 131, 5038-5039. doi: 10.1021/ja900436t

Schultz, M. P., Bendick, J. A., Holm, E. R., and Hertel, W. M. (2011). Economic impact of biofouling on a naval surface ship. Biofouling 27, 87-98. doi: 10.1080/ 08927014.2010.542809

Schultz, M. P., Walker, J. M., Steppe, C. N., and Flack, K. A. (2015). Impact of diatomaceous biofilms on the frictional drag of fouling-release coatings. Biofouling 31, 759-773. doi: 10.1080/08927014.2015.1108407

Selim, M. S., Shenashen, M. A., El-Safty, S. A., Higazy, S. A., Selim, M. M., Isago, H., et al. (2017). Recent progress in marine foul-release polymeric nanocomposite coatings. Prog. Mater. Sci. 87, 1-32. doi: 10.1016/j.pmatsci.201 7.02 .00 
Shaban, A. M., El-Taweel, G. E., and Ali, G. H. (1997). UV ability to inactivate microorganisms combined with factors affecting radiation. Water Sci. Technol. 35, 107-112. doi: 10.2166/wst.1997.0718

Shaw, K., Sesardić, I., Bristol, N., Ames, C., Dagnall, K., Ellis, C., et al. (2008). Comparison of the effects of sterilisation techniques on subsequent DNA profiling. Int. J. Legal Med. 122, 29-33. doi: 10.1007/s00414-007-0159-155

Sommer, R., Haider, T., Cabaj, A., Heidenreich, E., and Kundi, M. (1996). Increased inactivation of Saccharomyces cerevisiae by protraction of UV irradiation. Appl. Environ. Microbiol. 62, 1977-1983. doi: 10.1128/aem.62.6.1977-1983.1996

Sommer, R., Haider, T., Cabaj, A., Pribil, W., and Lhotsky, M. (1998). Time dose reciprocity in UV disinfection of water. Water Sci. Technol. 38, 145-150. doi: 10.2166/wst.1998.0526

Sylvester, F., and MacIsaac, H. J. (2010). Is vessel hull fouling an invasion threat to the Great Lakes? Divers. Distrib. 16, 132-143. doi: 10.1111/j.1472-4642.2009. 00622.x

Sylvester, F., Kalaci, O., Leung, B., Lacoursière-Roussel, A., Murray, C. C., Choi, F. M., et al. (2011). Hull fouling as an invasion vector: can simple models explain a complex problem? J. Appl. Ecol. 48, 415-423. doi: 10.1111/j.1365-2664.2011. 01957.x

Szabó, C., and Ohshima, H. (1997). DNA damage induced by peroxynitrite: subsequent biological effects. Nitric Oxide - Biol. Chem. 1, 373-385. doi: 10. 1006/niox.1997.0143

Tree, J. A., Adams, M. R., and Lees, D. N. (1997). virus inactivation during disinfection of wastewater by chlorination and UV irradiation and the efficacy of F+ bacteriophage as a "viral indicator". Water Sci. Technol. 35, 227-232. doi: 10.2166/wst.1997.0738

van de Waal, D. B., and Litchman, E. (2020). Multiple global change stressor effects on phytoplankton nutrient acquisition in a future ocean. Philos. Trans. R. Soc. B: Biol. Sci. 375, 1-8. doi: 10.1098/rstb.2019.0706

Wahl, M. (1989). Marine epibiosis. I. fouling and antifouling: some basic aspects. Mar. Ecol. Prog. Series 58, 175-189. doi: 10.3354/meps058175

Wahl, M., and Lafargue, F. (1990). Marine epibiosis. Oecologia 82, 275-282. doi: 10.1007/bf00323545

Werschkun, B., Sommer, Y., and Banerji, S. (2012). Disinfection byproducts in ballast water treatment: an evaluation of regulatory data. Water Res. 46, 4884-4901. doi: 10.1016/j.watres.2012. 05.034

Wetherbee, R., Lind, J. L., Burke, J., and Quatrano, R. S. (1998). Minireview-the first kiss: establishment and control of initial adhesion by raphid diatoms. $J$. Phycol. 34, 9-15. doi: 10.1046/j.1529-8817.1998.340009.x

Wickham, H. (2016). Elegant Graphics for Data Analysis. New York, NY: SpringerVerlag.

Winward, G. P., Avery, L. M., Stephenson, T., and Jefferson, B. (2008). Ultraviolet (UV) disinfection of grey water: particle size effects. Environ. Technol. 29, 235-244. doi: 10.1080/09593330802030069

Zelle, M. R. (1960). Biological effects of ultraviolet radiation. IRE Trans. Med. Electron. ME-7, 130-135. doi: 10.1109/IRET-ME.1960.5008034

Conflict of Interest: KR was employed by the company AkzoNobel.

The remaining authors declare that the research was conducted in the absence of any commercial or financial relationships that could be construed as a potential conflict of interest.

The handling editor declared a shared committee with several of the authors KR and $\mathrm{AC}$ at time of review.

Publisher's Note: All claims expressed in this article are solely those of the authors and do not necessarily represent those of their affiliated organizations, or those of the publisher, the editors and the reviewers. Any product that may be evaluated in this article, or claim that may be made by its manufacturer, is not guaranteed or endorsed by the publisher.

Copyright (c) 2022 Whitworth, Aldred, Reynolds, Plummer, Duke and Clare. This is an open-access article distributed under the terms of the Creative Commons Attribution License (CC BY). The use, distribution or reproduction in other forums is permitted, provided the original author(s) and the copyright owner(s) are credited and that the original publication in this journal is cited, in accordance with accepted academic practice. No use, distribution or reproduction is permitted which does not comply with these terms. 